Hannu Tommola

Tampere University

hannu.tommola@tuni.fi
УДК $811.16 / .17 ' 373.7$

https://doi.org/10.18485/slavistika.2020.24.2.4

оригинални научни рад

примљено 03.08.2020.

прихваћено за штампу 18.09.2020.

\title{
ОСТАТЬСЯ С НОСОМ И БЕЗ НОСА - ON CHANGING AND STAYING THE SAME
}

In many languages the verb denoting continuation of a particular state or condition ('remain, stay') seems - in some contexts - to be able to explicitly express a change in the state of the subject ('become'). The same happens in Slavonic languages, where, interestingly, the lexemes for both functions are derived from shared etymological origins, cf. Serbian nocma(ja)mu vs. ocma(ja)mu. The paper attempts to shed additional light on the conditions which make this kind of apparently paradoxical polysemy cross-linguistically possible. Apart from Polish zostać and Swedish bli that are the most intriguing cases in the corpus investigated, Livonian iedõ has been reported to share similar properties. In other Finnic languages and in the Baltic languages these features are found more or less sporadically.

Keywords: change of state, continuatives, copula, enantiosemy, Finnic languages, inchoatives, passive auxiliary, Polish zostać, Scandinavian bli(ve), Slavonic languages.

\section{Introduction}

Languages tend to have separate verbs to express change of state and absence of any change: e.g., English become vs. stay, remain, French devenir vs. rester, Russian сmamb vs. осmamьcя, or Estonian saama vs. jääma. ${ }^{1}$ This seems to be true at least in most European and some other languages that I have been able to check, including Turkish and other languages in the Turkic family, Georgian, Mandarin Chinese and Japanese. In Slavonic languages the most general verb for 'become' obviously shares its etymological origin with the verb for 'remain, stay'; 2 they often differ from one another merely by the prefix (or its absence), e.g. Slovene nastati, postati vs. ostati.

In many languages the verb denoting a direct denial of movement or other change in the state of the subject entity ('remain, stay') may, paradoxically, also express a transition into a new state. This type of polysemy could be called enantiosemy or autoantonymy, cross-linguistically attested primarily in the lexicon. ${ }^{3}$ Not just in

${ }^{1}$ Cf. also German werden vs. bleiben, Dutch worden vs. blijven; further Italian divenire vs. rimanere, as well as Latin fierī vs. (re)manēre; cf. also Baltic: Latvian klūt vs. palikt, and Lithuanian tapti vs. likti; from Finno-Ugrian languages cf., e.g. Finnish tulla vs. jäädä, and Hungrian lesz vs. (meg)marad.

${ }^{2}$ Cf. Polish stać się vs. zostać, Czech státi se vs. zůstat, Slovak stát' sa vs. (z)ostat', Bulgarian стана vs. остана, Ukrainian стати vs. зостатися, Serbian постати vs. остати.

${ }^{3}$ Both terms refer to words (sometimes also phrases or constructions) serving as their own opposite, e.g., sanction both in the sense of 'permission' and 'ban'. As a matter of fact, however, it is often difficult to decide whether we have to do with enantiosemes or polysemes; thus in sociology, for example, sanctions can be either positive (reward) or negative (punishment) 'means of enforcing rules.' As to the case of rent (and corresponding verbs observed in several languages) denot- 
Slavonic but in all the languages considered here (though to different extents and in various contexts) the "wrong" lexeme, as it were, is used to express the change of state. This happens often in conventionalized contexts, like in constructions of 'being left orphan / widowed' (see ex. (3)).

Worth of special attention are the cases where the verb for 'remain, stay' has been grammaticalized also in the inchoative function, so that one lexical verb can regularly be used to express either of the functions. Such are Polish zostać and bli(ve) in Continental Scandinavian, represented in my material by Swedish bli. According to Weiss (1982), the inchoative use of the initially only continuative Polish zostac was calqued from Middle Low German where bliven was used in this function. Since bli(ve) was adopted into Scandinavian as a lexical borrowing from the same source, it is plausible that it was copied with the functions of the MLG verb, too, as suggested by Weiss. ${ }^{4}$ It needs to be reminded what Wiemer (1998: 198, referring to Weiss 1982: 199f) states about the situation in Polish: the prefixed pozostać as an unambiguous continuative copula has partly taken the place of zostać in this meaning (reflected also in my sample, not only in Ex. (2)). The same happens with Swedish bli, which has virtually become an inchoative copula, while there are unambiguous continuatives available, like förbli and stanna.

Unfortunately, Finnic languages are not included in the parallel material used, but it is reported that Livonian iedõ 'stay; remain' is typically used to express change "in the widest sense in a variety of constructions" (Norvik 2020: 182). Its cognates in other Finnic languages are used in the inchoative function just to some extent, notably in Estonian (jääma) and Votic $(j a ̈ a ̈(v) v \ddot{a})$, and overwhelmingly in negative contexts at that (Norvik 2020: 171, 181). According to Norvik (2020: 190) Latvian palikt 'remain, stay', which is attested with the 'become' meaning (to a greater extent in spoken language), "has evidently had influence on the Livonian iedô". 5

In this paper, I explore the contexts where one of the verbs with a core meaning 'remain, stay' 6 is used in any of the languages of a parallel translational corpus, consisting of most Slavonic and a number of other languages. Besides Polish zostać, having clearly two-fold semantics, an additional focus is on Swedish bli, which shows similar bipolar polysemy. The empirical data is drawn from Barentsen's Amsterdam Parallel Corpus (ASPAC). For the present article mainly Stanisław Lem's Solaris and

ing both 'hire' and 'rent out', they should rather be regarded as auto-converses than auto-antonyms (Wiemer 2008: 404).

${ }^{4}$ The cognates of LHG blîven in Middle or Old High German (belīben, bilīben) have not been attested with this polysemy, nor Gothic bileifjan. - For a thorough account of the development of inchoative copulae in Russian, Polish and Lithuanian, see Wiemer 1998.

${ }^{5}$ In addition to the virtually extinct but revived Livonian, also Luts, the dialect spoken by Ludza Estonians in Latvia, shows the polysemy of 'remain, stay' and 'become' (Norvik 2020: 183). Having no primary data from the Baltic languages, I do not suggest any generalizations. However, in view of the fact that also Lithuanian likti 'remain' seems to show cases of this polysemy, one might imagine that we have to do with an areal isogloss.

${ }^{6}$ Of course, both English verbs are polysemic, having meanings not shared by the other. Thus, in principle they are not suitable to cross-linguistic comparisons. In the absence of a proper metalanguage I for convenience refer to both 'remain' and 'stay' as a prototype of the piece of verbal semantics under investigation. 
Astrid Lindgren's Pippi Långstrump were thoroughly investigated, as well as their translations into a number of languages. ${ }^{7}$ Solaris comprises 56,053 running words, its translations between 55,000 and 75,000 each. Pippi in the ASPAC counts about half of the length of Solaris; additionally Lindgren's Karlsson på taket was considered, which means that the subcorpora of texts written in Polish and Swedish are roughly of equal size. However, the main bias comes from the fact that while there are Polish translations of the Swedish originals, there were no translations available from Polish into Swedish.

\section{Four types of contexts for Russian ocma(ва)mься 'remain, stay'}

In examples ((1) through (4)) different contextual readings of Russian ocma(ва) ться are illustrated. Ex. (3) represents the allegedly paradoxical case that actually interests us; it also exhibits one of the conventionalized contexts where 'remain' is cross-linguistically typical with a change-of-state meaning. Examples (1) and (2) demonstrate cases where in Slavonic languages imperfective and perfective past is used, respectively, while the interpretation of (4) is questionable (see below). It is followed by (5) and (6), where the inchoative meaning 'stop moving' is unmistakable, but probably infrequent in Slavonic languages.

In (1) the imperfective оставалось in the Russian translation corresponds to byto jeszcze of the Polish original, which ascertains the interpretation of оставаться as a continuative copula.

(1) (Pol) Tylko u samego zenitu niebo było jeszcze zawzięcie rude. (Lem, Solaris) (Rus) Только у самого горизонта небо упорно оставалось рыжим.

(Eng) The sky was red only at the zenith.

The perfective pozostała of the Polish source text in (2) is, not surprisingly, rendered into Russian as осталась. In the translations into other Slavonic languages the perfective past is used in all but one. ${ }^{8}$ In the translations of the two non-Slavonic languages of the sample, perfect (Dutch is gebleven) and present (English remains) were chosen. One can argue that a copular verb could be used here as well: either a perfective past (e.g., Russian явилась) or the present (и все еще является).

(2) (Pol) ... teoria ..., która, choć porzucona jako fałszywa, pozostała wspaniałym wzorem myślowego rozmachu i logicznego konstruktorstwa. (Lem, Solaris)

(Rus) ... теория ..., которая, хоть и была отвергнута как ложная, все же осталась великолепным примером интеллектуального размаха и логики.

${ }^{7}$ All available translations were included: of Solaris into Belarusian (abbr. Blr), Bulgarian (Blg), Croatian (Cro), Czech (Cze), Russian (Rus), Serbian (Srb) and Ukrainian (Ukr), plus Dutch (Dut) and English (Eng); of Pippi into Bulgarian, Croatian, Czech, Russian (two translations), Ukrainian, as well as into Dutch, English and German (Grm). More sporadically studied were translations of Stieg Larsson's Män som hatar kvinnor (Millennium), and with originals in English and Dutch, respectively: Douglas Adams' The Hitch Hiker's Guide to the Galaxy and Anne Frank's Diary.

${ }^{8}$ The Bulgarian translation with остава seems to be an exception that proves the rule, if it is the present (like in the English translation); in fact, however, it can be an aorist. 
(Eng) ... theory ... which has since been shown to be inaccurate, but remains a superb example of intellectual audacity and logical construction.

Ex. (3) is a typical example of the paradoxical use of 'remain, stay' verbs that occur in idiomatic constructions in a wide range of languages, even where the distinction between continuative and inchoative copulas otherwise is maintained. Observe that the change implied here is in most cases pragmatically interpreted as negative. As mentioned above, it has been pointed out that negative contexts have predominance among the occurrences of 'remain' with inchoative meaning in Finnic languages. Negative context (in constructions with negated adjectives and participles) as a trigger of the development of Polish zostać was suggested by Weiss (1982), and adopted by Wiemer (e.g., 2004: 300).

(3) (Rus) Ребёнок остался сиротой. (Apresjan \& Páll 1982, 1: 769)

(Ita) Anna è rimasta orfana. 'Anna was left an orphan.' (Strik Lievers 2014)

(Est) Ta jäi orvuks. 'S/he was left an orphan.'

(Hun) A gyermekek árván marádtak. 'The children were left orphans.'

The context in (4) is not quite clear: either it shows a colloquial use of the Russian perfective imperative synonymous in the meaning with остановиться 'stop', or it may be from a situation where the addressee is only considering to leave, i.e. ocmaнb$c я$ has the original continuative meaning of 'remain'. In turn, (5) and (6) are clear cases of 'stop' (with no Slavonic 'remain').

(4) Куда ты идёшь? Останься, прошу тебя. (Apresjan\&Páll 1982, 1: 766)

'Where are you going? Please, stay!'

(5) (Swd) "Avdelning HALT!" Hon stannade. (Lindgren, Pippi Långstrump)

(Cze) „Zastavííít stát!“ A zůstala stát.

“Company, HALT!' She stopped.'

(6) (Swd) Då hon kom mitt för Tommys och Annikas grind, stannade hon. (Lindgren, Pippi)

(Cze) U vrátek, kde stál Tomy s Anikou, se zastavila.

(Dut) Toen ze vlak voor Tommy en Annekes hek kwam, bleef ze staan.

(Grm) Als sie vor Tommys und Annikas Gartentür angekommen war, blieb sie stehen.

(Pol) Gdy dotarła do furtki Tommy'ego i Anniki, przystanęta.

'When she came level with Tommy and Annika's gate, she stopped.'

The continuative verbs in the function of 'stop' are apparently not common in Slavonic languages, and Czech zuistala stát in (5) can be a calque from German; see the possible source in (6) where Swedish stanna (capable of expressing both 'remain, stay' and 'stop') is translated with complex verbs into German and Dutch. 


\section{3. "Existential" remain $=$ 'still exist' $(\neq$ stay $)$}

While in English remain and stay as continuatives are near synonyms, they both have additional meanings in which they cannot be replaced by each other. The Cobuild Dictionary (1987) defines stay as referring to a situation where the subject is in a place or in a particular state or situation and continues to be there or in it. Remain, again, is explained through stay: remaining 'in a place' or 'in a particular state or condition' means staying there or 'in that state or condition' and not moving away or changing. Stay is not readily suitable to replace remain in contexts like "it remains to be seen", neither is remain probably expected to replace stay in contexts as "it has come to stay".

Let us have a look at a function of remain which does not seem to be shared by stay: 'something remains when it still exists' (Cobuild 1987). In (7), presenting translations from the Polish original, most languages of our sample use in this meaning the standard continuative verb, even though the English translator has taken an easy option. Unlike the original and the Czech, Belarusian, Croatian and Bulgarian translations, Russian and Ukrainian use the perfective aspect here. It is hard to see any significant difference in the meaning between the aspects here, even if the perfective openly implies future time reference.

(7) (Pol) Inaczej zostaje tylko zazdrościć G. (Lem, Solaris)

(Cze) Jinak nezbývá než jenom závidět G.

(Bel) Інакш застаецца толькі зайздросціць Г.

(Blg) Иначе остава само да завиждаме на Г.

(Cro) Inače nam ostaje samo zavidjeti G.

(Rus) Иначе останется только позавидовать Г.

(Ukr) Інакше залишиться тільки позаздрити Г.

(Dut) In het andere geval rest ons slechts G. te benijden.

(Eng) Otherwise, we can only envy G.

The Czech translation in (7) demonstrates a continuative specialized for this function, zbý(va)t 'remain', here a negated present form nezbývá. ${ }^{9}$ The Dutch translator has, too, instead of the standard blijven 'remain', chosen a word with this narrower meaning: resten. The Janus-faced Scandinavian bli 'remain; become' is rare in this meaning, e.g. in Swedish giving place to lexicalizations, like Dutch resten confined to this meaning, see (8).

(8) (Swd) ... allt som kunnat sägas hade redan sagts. Att han skulle fällas hade han inte för en sekund tvivlat på. ... nu återstod endast en slutsummering från de reportrar som väntade i korridoren utanför tingsrätten. (Larsson, Millennium) (Pol) ... wszystko, co było do powiedzenia, zostało już powiedziane. Mężczyzna ani przez sekundę nie wątpił, że zostanie skazany. ... teraz pozostało tylko uzasadnienie i komentarze reporterów czekających przed budynkiem sądu rejonowego.

\footnotetext{
${ }^{9}$ In this kind of contexts typically adverbs meaning 'only' occur, here in all language versions. In Czech frequent are jen, jenom, pouze, pouhé, and with the negation as here, než 'than', and nic jiného 'nothing else'.
} 
The verb àterstå of the original is rendered in Polish with the perfective pozostać. Besides, the preceding text in (8) demonstrates two instances of Polish zostać with a passive past participle translating the Swedish $s$-Passive. ${ }^{10}$ The Swedish bli would, in fact, deserve a more detailed account. In what follows (section 4.), I just offer a brief comparison based on the relevant contexts included in my corpus.

\section{4. 'Remaining' and 'becoming' in Swedish originals and in their Polish translations}

In view of the somehow similar status of bli and Polish zostać - both being not only capable of rendering the meanings 'remain' and 'become', but also of forming the eventive passive - it may appear curious that in my data there are not very many occurrences of mutual translations.

Out of a total 100 occurrences of bli in the original Pippi Långstrump not more than four instances demonstrate continuative meaning (9) ${ }^{11}$, and there are just as many occurrences of stanna with this meaning. All continuatives have been translated into Polish with zostać. Incidentally, there are about 20 occurrences of bli as future copula, which is sometimes hard to distinguish from the inchoative use. ${ }^{12}$ In the Polish translation the copula być is used here, primarily in future (10).

(9) (Swd) "Vi kanske blir där hela dan", sa Annika.

(Pol) Może zostaniemy u niej przez cały dzień - dodała Annika.

(Eng) 'We might stay all day!' added Annika.

(10) (Swd) Men kom alltid ihåg hur många äpplen Axel hade, annars blir ni olyckliga.

(Pol) Ale pamiętajcie zawsze, ile jabłek miał Axel, w przeciwnym bowiem razie będziecie nieszczęśliwi!

(Eng) But always remember how many apples Axel had, else you'll come to a bad end, ...

The major part of occurrences of bli (approx. 60) represent instances of inchoative copula, while only seven of them are rendered into Polish with zostać (11). In the great majority of the cases, in Polish, the change-of-state element is lexicalized in inchoative verbs, often derived from an adjectival root (12). A couple of occurrences demonstrate another state-of-change verb with an adjective complement (13), manifesting the difference of bli and zostac in their colligational capacity.

${ }^{10}$ The grammaticalization of the passive constructions employing verbs showing the evolution remain $\rightarrow$ become deserves to be studied cross-linguistically with more space and time. For good accounts see Wiemer 2004 and Wiemer \& Hansen 2012.

${ }^{11}$ It is better not to give exact numbers, because there are cases, where it is difficult to decide whether we have to do with a continuative or a future copula. The same ambiguity is sometimes encountered between continuative and inchoative reading (see, e.g., the last example discussed in Conclusions), and inchoative reading easily applies to cases of eventive passive - what is indeed manifested by one of the possible developments of inchoative verbs, see (14) where Swedish bli with the participle of the corresponding causative is rendered in Polish with zostać.

${ }^{12}$ Dahl (2000) discusses the grammaticalization path from 'become' to 'will be', "manifested within the North European 'futureless area"” (Dahl 2000: 360). 
(11) (Swd) "Jaså, du hade inte blitt hembiträde den här gången", sa Pippi... (Pol) - Aha, więc tym razem nie zostałeś stużacą? - powiedziała Pippi... (Eng) 'So you didn't become a butler this time,' said Pippi ...

(12) (Swd) "Nog kan man väl bli arg på Herr Nilsson”, sa Pippi. (Pol) Można się naprawdę zezłościć na tego Pana Nilssona - mówiła Pippi... (Eng) 'I get really angry with Mr Nelson,' said Pippi.

(13) (Swd) Det var först varmt och vått och sen blev det kallt och vått...

(Pol) Najpierw było ciepło i mokro, a potem zrobiło się zimno i mokro ...

(Eng) ...; it was warm and wet at first, and then cold and wet, but it didn't matter at all ...

Although both bli and zostać are used as passive auxiliaries, both Swedish and Polish have other means, too, to express passive. Also, as is seen from (14), inchoative meaning can be argued to be inherent in the meaning of zostać without an actual change of state.

(14) (Swd) För en sån liten apa var det ju inte så roligt att bli lämnad ensam i skogen. (Pol) Dla małej małpki to wcale niezabawne zostać samotnie w lesie.

(Eng) It wasn't much fun for such a little monkey to be left alone in the woods.

\section{Significance of negative context - some evidence from Finnic}

\subsection{On inherent negation of 'remaining'}

In (Томмола 1986) the common actional semantics of Fin. jä̈̈dä and Russian perf. остаться was labelled by means of an antonymic characterization as 'resultative non-change' ("результативное неизменение"). It can be argued that in the semantics of these verbs a pragmatic presupposition is cancelled. That is, when I say 'I'll stay at home', I assume that the addressee knows that I have some kind of option to go out, as well. The Finnish jä̈̈dä was analysed as a special case of "resultative" events in the actional taxonomy in (Томмола 1986), along with the corresponding transitive jättää 'leave'. In its aspectual behaviour jättää complies with the object marking rules signaling "total affectedness", and, in fact, inherent telicity. It is maintained both in (Томмола 1986) and (Tommola 1995) that Finnish jäädä in comparison with Russian actually corresponds only to perfective ocmamb$c я$, whereas there is another verb (pysyä) that is the nearest equivalent to Russ. imperfective оставаться.

The actional difference between pysyä and jäädä is also emphasized by Huumo (2007): the former is "static and unbounded", the latter "dynamic and bounded". Moreover, he points out that "remaining' itself is a punctual event and the verb jääd indicates a change of state, even though the state that ... precedes the event is often similar to the state that follows it."13 What Huumo means with "a punctual event"

${ }^{13}$ Theoretically Huumo adopts concepts of cognitive linguistics, "force dynamics" and "fictive dynamicity" (see, for example, Talmy 2000), to explain the lative locative arguments that jäädä takes, as well as similar behaviour of a group of other Finnish verbs requiring dynamic complements (e.g. löytää 'find' with elative or ablative modifiers). Thus, he proposes that, for instance in 
may be interpreted as referring to the "left-boundary" of the "new" state which as a matter of fact remains identical with the preceding. Discussing Polish zostac Wiemer (2004: 298-299), too, speaks of punctualness, and of the implicit negation involved in its semantic structure. ${ }^{14}$

Let us consider (15), where Swedish stanna ('remain'/'stop') - unlike (5) and (6) above - conveys continuative function.

(15) (Swd) Han BORDE ha fătt stanna hemma och loppat hästen. (Pippi)

(Rus) Почему я не оставила господина Нильсона дома? Сидел бы себе там ... (Cze) Měla jsem Pana Nilsona nechat doma, mohl chytat koni blechy.

(Eng) He should have been left at home to mind the horse....

(Grm) Er hätte zu Hause bleiben und das Pferd flöhen sollen....

(Pol) Powinien był zostać $w$ domu i wyłapywać pchły na koniu! ...

The German and Polish translators use the standard continuative, while the Russian, Czech and English translators have chosen to transfer it with a corresponding causative verb. Some negative element (in the original aldrig 'never') is involved in all the translations in the context. ${ }^{15}$

\subsection{Polish zostać vs. Finnish jääd}

In view of the Polish "ambivalent" zostać, let us consider one of this verb's meanings illustrated in Komputerowy Stownik Języka Polskiego (1998):

(16) zostać 4. «znaleźć się w jakimś położeniu, w jakiejś sytuacji (zwykle przykrej)»

1) Zostać bez grosza.

2) Zostać bez dachu nad głową.

3) Oddział został bez dowódcy.

4) Zostać na placu «zwyciężyć, zmusić przeciwników, rywali do ustąpienia»

5) Zostać przy swoim «nie zmienić zdania, opinii o czymś»

6) Zostać przy życiu «nie umrzeć, nie zginąć»

According to the dictionary explanation, the reference in this function is usually made to "unpleasant" situations. Interesting hereby is, in the first place, that only the three first examples clearly do this; 4) and 6) are positive, 5) in this respect neutral. In the second place, it may be a curiosity that all the examples happily translate

the case of $j \ddot{a} \ddot{a} \ddot{a}$, a fictive change is indicated, which leads to a static situation. This analysis seems to accord with the idea of cancelled presupposition and to be cross-linguistically applicable.

${ }^{14}$ Wiemer (2004: 298): "The aspectual default of zostać was right from the start of its development into an auxiliary a punctual one (see below). This must be understood in the sense that zostac at all times lexicalized the negation of the inception of a new state..." (my emphasis - HT)

${ }^{15}$ It is apparently a coincidence that the structure of the Czech transitive nechat seems to suggest what is involved in the concept both of the continuative intransitive and the corresponding causative verbs. The morphologic form of the Czech causative with the seemingly negating $n e$ - may intrigue one to imagine that it reflects the implicit negative element in the semantics of the verb. 
into Finnish with jääd 'remain', but is it really a coincidence that it is in the first three "unpleasant" situations only (with bez 'without' in Polish) where zostać / jäädä implies a new situation? In the other three cases the previous state continues to prevail, even if the situation is conceived of as new by the subject.

\section{Conclusion}

The limited space in a short article does not allow to give a complete description of the means to express the concept of 'remaining' represented in the corpus. After all, the central aim with this paper has been to attempt to conceive the fundamental basis of differently interpreted facts behind seemingly one and the same expressions. Let us, to conclude, look at one more example from my data.

(17) (Swd) När fröken och Pippi blev ensamma, reste Pippi på sig och gick fram till katedern. (Lindgren, Pippi Långstrump)

(Pol) Gdy zostały same, Pippi wstała i podeszła do katedry.

(Eng) When the teacher and Pippi were alone, Pippi got up and came forward to the desk.

There are two ways to grasp, or two points of view to look from at the situation in (17): 1) for the children who went out, the teacher and Pippi stayed in; whereas 2) for the teacher and Pippi, this fact created a new situation, for them it was a change of state.

The same pragmatic analysis is valid in constructions of being left orphan or widowed (see (3)), provided that we accept there being two versions of viewing points: that of the orphan (or widow) and that of the deceased. However, (17) is different from (3) in that there is not necessarily anything that should be qualified as "negative".

The development of Polish and Swedish inchoatives has been explained in Weiss (1982), Wiemer $(1998,2004)$ and Wiemer \& Hansen (2012). Not only have the initially continuative verbs in these languages grammaticalized as inchoative copulas, but they have also developed into homonymous passive auxiliaries. This has not been shown of Livonian iedõ, and as a whole the topic would still deserve cross-linguistic research in the Finnic languages, not least to examine possible Germanic and Baltic influence.

\section{Literature}

Apreszjan, Juri, Erna Páll. Orosz ige - Magyar ige. Vonzatok és kapcsolódások (Русский глагол - венгерский глагол / Управление и сочетаемость), 1-2. Budapest: Tankönyvkiadó. 1982.

ASPAC $=$ Barentsen, A.A. Amsterdam Slavic Parallel Aligned corpus; available at the National Corpus of the Russian Language as a parallel (multi-language) corpus of translated texts with the originals. https://ruscorpora.ru/new/en/index.html

Cobuild = Collins Cobuild Dictionary. HarperCollins Publishers, 1987.

Dahl, Östen. "Verbs of becoming as future copulas." [In:] Dahl, Östen (ed.) Tense and aspect in the languages of Europe. Empirical Approaches to Language Typology. EUROTYP 20-6. Berlin \& New York: Mouton de Gruyter. 2000, 352-361. 
Huumo, Tuomas. "Force dynamics, fictive dynamicity, and the Finnish verbs of 'remaining"'. [In:] Folia Linguistica 41, 2007, 73-98. [DOI: 10.1515/flin.41.1-2.73]

KSJP = Komputerowy Stownik Języka Polskiego. CD-Rom. PWN, 1998.

Norvik, Miina. "The expression of CHANGE-OF-STATE in the Finnic languages". [In:] De Guyter: Open Linguistics 2020; 6: 171-195 https://doi.org/10.1515/opli-2020-0013

Strik Lievers, Francesca. "Remain' verbs in Romance. A case of state / transition polysemy". Abstract. Chronos 11. (11th International Conference on Actionality, Tense, Aspect, Modality/Evidentiality), Scuola Normale Superiore, Pisa, 16-18 June 2014. (http://linguistica.sns.it/Chronos11/Abstract/174_Strik\%20Lievers.pdf)

Talmy, Leonard. 2000. Toward a cognitive semantics. Volume I: Concept structuring systems . Cambridge, MA: The MIT Press.

Tommola, Hannu. "States they are a'changin': on the semantics of 'remain' and 'become"" [In:] Bertinetto, Pier Marco et al. (eds.) Temporal Reference, Aspect and Actionality: Semantic and Syntactic Perspectives, vol. 2. Torino: Rosenberg \& Sellier. 1995, 125-140.

Weiss, Daniel. „Deutsch-polnische Lehnbeziehungen im Bereich der Passivbildung“ [In:] Reißner, (ed.). Literatur- und Sprachentwicklung in Osteuropa im 20. Jahrhundert. Berlin. 1982, 197-218.

Wiemer, Björn. „Пути грамматикализации инхоативных связок (на примере русского, польского и литовского языков)" (Puti grammaticalizacii inxoativnyx svjazok (na primere russkogo, pol'skogo i litovskogo jazykov) [In:] Studia Slavica Oldenburgensia, 2. 1998, 165-212.

Wiemer, Björn. "The evolution of passives as grammatical constructions in Northern Slavic and Baltic languages" [In:] Bisang, Walter et al. (eds.). What makes Grammaticalization? A Look from its Fringes and its Components. Berlin \& New York: Mouton de Gruyter. 2004, 271-331.

Wiemer, Björn. „Zur Enantiosemie im strikten Sinn: zwischen Pragmatik und (lexikalischer) Semantik“ [In:] Brehmer, B. u.a. (Hgg.) Aspekte, Kategorien und Kontakte slavischer Sprachen (Festschrift für Volkmar Lehmann zum 65. Geburtstag). Studien zur Slavistik 16. Hamburg: Dr. Kovač, 2008, 404-416.

Wiemer, Björn \& Björn Hansen. "Assessing the range of contact-induced grammaticalization in Slavonic" [In:] Wiemer, Björn et al. (eds.). Grammatical replication and borrowability in language contact. Trends in Linguistics, Studies and Monographs, 242. Berlin, New York: Mouton de Gruyter. 2012, 67-155.

Томмола, Ханну. Аспектуальность в финском и русском языках. (Aspektual'nost $\mathrm{v}$ finskom i russkom jazykax) [= Yearbook of the Institute for Cultural Relations between Finland and the USSR, 28]. Helsinki: Neuvostoliittoinstituutti, 1986. 


\title{
Хану Томола
}

\section{ОСТАТИ С НОСОМ И БЕЗ НОСА - О ПРИСТУПАЬУ И ОСТАЈАЮУ У ЈЕЗИКУ}

\begin{abstract}
Резиме
Обично у језицима постоји један глагол за изражавање преласка у ново стање и други за непостојање промене стања. Управо у устаљеним изразима („остати сироче“ и др.), као да „погрешна“ лексема врши улогу показатеља новог стања. У словенским језицима ови глаголи деле заједничко порекло, нпр. српски поста(ja)mu vs. ocma(ja)mu. Понекад су инхоативно и континуативно значење лексикализована у једном глаголу, нпр. пољско zostać и шведско bli имају несумњиво двојну природу. У овом раду су проучени у овом смислу релевантни глаголи у словенским и у низу несловенских језика. Емпиријски материјал је прикупљен помоћу Барентсеновог паралелног корпуса (ASPAC).

Приликом одређивања теоријске основе двојаке интерпретације концепта „остати“ од користи може бити нађени у закључку пример (17), где протагонисти „остају сами“. Могућа су два алтернативна угла гледања на ситуацију: 1) из угла деце која су изашла, док су учитељица и Пипи остале у учионици; или 2) из угла учитељице и Пипи које јесу остале у учионици, али за које то што су се сад нашле саме представља прелазак у ново стање.

У чланку се анализира двојакост појма 'остајања' као „резултативног немењања“, тј. као нечег што у свом значењу скрива пресупозицију која се поништава. Поклања се пажња и извесној „негативности“ контекста у којима континуативни глаголи добијају инхоативно значење. Важно место у истраживању заузима анализа преношења шведског bli у пољском преводу и покушај одређивања разлика у употреби датих многозначних глагола у разним својим значењима.
\end{abstract}

Кључне речи: инхоативи, континуативи, пољко zostać, балтичко-фински језици, скандинавско bli(ve), словенски језици, енантиосемија. 